\title{
Editorial
}

\section{Elenor Kunz}

Editor

Com a presente revista estamos inaugurando e também, de certo modo, verificando a possibilidade de conseguirmos manter uma publicação de três números anuais. Fica esse número como uma edição especial não temática. De qualquer modo, estamos, também, preparando o último número para esse ano a ser publicado até dezembro. Artigos para esse número ainda podem ser encaminhados a nossa Revista e dependendo das avaliações dos nossos pareceristas, possíveis de serem publicados.

Nunca é demais lembrar, que as exigências de publicar pesquisas, investigações acadêmicas especialmente, é cada vez maior e não apenas em programas de pósgraduação e aos profissionais que atuam nelas como professores e alunos, mas inclusive com os demais profissionais universitários e seus alunos mesmo não participantes de um programa de pós-graduação.

Assim, é imperioso que revistas menos "qualis'ficadas" recebam um estimulo e sejam, também, lembradas não apenas aos "necessitados" de publicação, mas a todos aqueles que pesquisam e sentem a necessidade de socializar conhecimentos e resultados de suas investigações. Desta forma é possível publicar o maior número de pesquisas no âmbito acadêmico ou fora dele e garantir além da periodicidade da revista, uma maior abrangência de publicações e melhorar a qualidade destas bem como da revista como um todo. Esta é a meta da Revista Kinesis daqui para frente. Queremos conseguir para o ano que vem a publicação regular de três números e manter sua periodicidade e incluí-la em alguma agência de avaliação de revistas para melhorar seu Qualis.

Para esse número conseguimos a aprovação de alguns artigos de grande relevância embora nossa pretendida abrangência temática ainda não estivesse plenamente atendida, ou seja, nossa Revista ainda recebe o maior numero de seus artigos da área pedagógica e, embora consideramos que essa seja uma área mais carente de possibilidades de publicação no País hoje, queremos estar abertos para outras áreas temáticas também. 
Neste número então, recebemos e estamos publicando o maior número de artigos que se referem à Escola e ao Ensino dos Esportes, como, por exemplo, nos artigos: "Preferência de atividade física e esportes para escolares no ensino fundamental", "O esporte como conteúdo hegemônico das aulas de Educação Física em uma escola de Anápolis;" "O esporte da/na Escola nas políticas públicas em Santa Catarina"; "Esportivização de um Jogo"; "Infografia como objeto educacional ao ensino do Atletismo" e "As competições infanto/juvenis à luz da pedagogia do esporte". E, conseguimos apenas dois artigos que não tratam diretamente desse assunto porque investigaram sobre o "Perfil psicomotor da noção de corpo de pré-escolares de uma creche-escola de Fortaleza" e "O Samurai como metáfora da Sociedade Japonesa".

Destacamos por último, que devido as dificuldades que temos com avaliadores para as mais variadas temáticas, estamos solicitando e oficializando já para os próximos números que os autores encaminhem junto a seus artigos, sugestão de avaliadores, desde que respeitada as normas técnicas da Revista. 